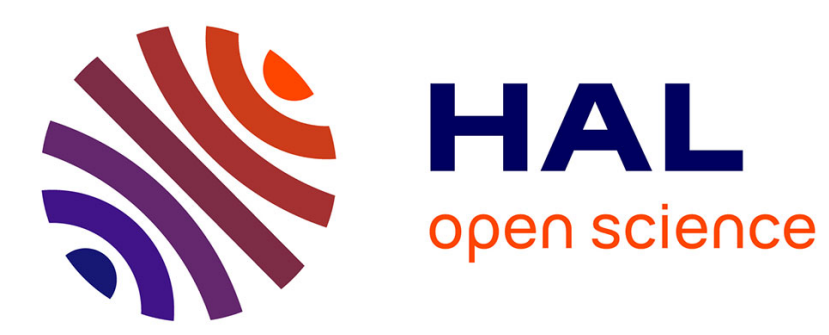

\title{
The Spirit as the Subject Carrying out the Sublation of Nature
}

\author{
Gilles Marmasse
}

\section{To cite this version:}

Gilles Marmasse. The Spirit as the Subject Carrying out the Sublation of Nature. Bulletin of the Hegel Society of Great Britain, 2009, 59-60, pp. 19-31. halshs-00673378

\section{HAL Id: halshs-00673378 https://shs.hal.science/halshs-00673378}

Submitted on 23 Feb 2012

HAL is a multi-disciplinary open access archive for the deposit and dissemination of scientific research documents, whether they are published or not. The documents may come from teaching and research institutions in France or abroad, or from public or private research centers.
L'archive ouverte pluridisciplinaire HAL, est destinée au dépôt et à la diffusion de documents scientifiques de niveau recherche, publiés ou non, émanant des établissements d'enseignement et de recherche français ou étrangers, des laboratoires publics ou privés. 


\section{The Spirit as the Subject Carrying out the Sublation of Nature}

We know that for Hegel the notion of spirit takes so many shapes that their unity is difficult to find. For instance, what does the soul in the subjective spirit, the property in the objective spirit and the cult of the Greek gods in the absolute spirit have in common? Furthermore, when we consider property, for example, the problem is knowing if the spirit is here constituted by the owner, by the deeds of ownership or by the living relationship between the owner and the possessed goods.

Moreover, the Hegelian spirit is a philosophical descendant of several different traditions. The question is, therefore, to know how these traditions are linked in the Hegelian notion. I will present these briefly before stating my general hypothesis about the definition of the spirit.

First, the Hegelian spirit is connected to the noûs of the Greek philosophers (the Latin spiritus, intellectus). The noûs — on the one hand, an immaterial entity leading the universe, and, on the other, a faculty of the soul — is most often distinguished by its separate and rational nature. For Hegel too, the spirit, as a non-perceptible entity, constitutes the freest and most rational stage in the development of the Idea.

Second, the spirit is linked with the ancient philosophers' pneûma (the Latin spiritus), the breath of life. A material principle governing the universe for the Stoics, the term became highly theologically charged within the Hebrew and Christian traditions. It translates the Hebrew term 'ruab': the breath of Yahweh. The pneuma is also considered by the Christians as God establishing Himself in the world and in men. Similarly, for Hegel, the spirit includes a theological element and most notably constitutes itself as the soul of the Christian community, that is, as Holy Spirit.

Third, for the moderns, the notion of the spirit is linked to the problem of the relation between soul and body. The spirit (mens, animus) taken by Descartes as equivalent to the rational soul (anima), is so to speak the body's and matter's counterpart. According to Descartes, the spirit is indivisible and non-spatial, playing no role in the organic functions of human life, but is fundamentally characterised by the understanding and the will. For Hegel too, as an entity opposed to the natural body and nature in general, as a unifying agent or subject, the spirit is characterised by its ability to know itself and to give itself a practical law.

Fourth, the eighteenth century saw the emergence of the concept of the spirit of the people. Similarly, for Hegel, the spirit does not develop in the individual consciousness alone but manifests itself in historically and geographically situated peoples, and expresses itself through their deeds.

Finally, for Fichte, the 'I' produces itself by its original act and, at the same time, produces the world as its object. Being and acting are in this way identical. The ' $\mathrm{I}$ ' does not stop at any given stage but actively surpasses all limitations. The Hegelian 
spirit also defines itself by its activity, an activity of self-production that opposes the spirit to any fixed determination.

However, beyond these borrowings, our question concerns what might be considered to be the fundamental element of Hegelian conceptualisation. My hypothesis shall be that the spirit defines itself essentially as the instance of sublation [Aufhebung] of naturalness [Natürlichkeit] in the sense of the presupposed given manifold. More precisely, it is neither something inert, nor an activity without a subject, but an active subject that, in theoretical and practical ways, builds itself as the unifying principle of naturalness - both exterior nature as well as itself as a simple presupposition. My aim in the first part of the paper is to show how the relation of sublation that the spirit maintains to naturalness is constitutive of its various shapes. I will then consider, in the second part, the question of the naturalness of the spirit itself. Finally, I will reflect on the spirit's origin: how can it proceed from itself and yet constantly reinvent itself?

\section{The Spirit as a Subject Transposing Nature's Multiplicity into a Unitary Knowledge and Will}

Can we propose a general characterisation of the spirit? In my view, the spirit is the subject giving itself actuality [Wirklichkeit] by carrying out the sublation of the real otherness, which appears to be a naturalness.

By 'sublation', I understand the operation by which a subject renders an object 'ideal' [ideell, by making it the subordinate material that allows the subject to affirm its own fulfilment. As negation of the negation, the sublation is the act by which a subject constitutes itself as a totality by taking charge of the given manifold in its own unity. The subject introduces a universal principle into what is originally particular, i.e., plural. There is a subordination of the other but also a making use of it. Through the sublation, the subject suppresses, negatively, the opposition between itself and the other but also establishes. positively. the unity between itself and the other through the subordination of the latter.

In my view, the Hegelian sublation is fundamentally linked to Kant's synthesis, although it is not the same concept. 1) For Kant, indeed the manifold is not characterised by the contradiction, which is the case in Hegel. 2) For Kant, the synthesis can remain unnoticed, whereas, for Hegel, the sublation is always manifest. 3) For Kant the spirit does not necessarily need to carry out a synthesis to exist, whereas for Hegel the spirit cannot exist without action, i.e., sublation. 4) For Kant, the synthesis can be pure, whereas, for Hegel, the sublation always refers to a particular object. 5) Kant does not speak in the three Critiques of the formational process [Bildung] of the spirit, for him the spirit seems to be always already given. For Hegel, on the contrary, the spirit builds and transforms itself through the sublation. 6) 
Finally, the Kantian synthesis simply gathers what is separate, whereas the Hegelian sublation implies a change of status, namely, from the real given to the ideal knowing and willing. For example, it is the transposition of the materiality of an area of land into ideal property deeds, or the transposition from the brute marble to the meaning of the Apollo sculpted in the marble.

In spite of these differences, the Hegelian sublation is an heir to the Kantian concept of spontaneous synthetic activity. Hegel takes up the Kantian conviction according to which the spirit is not restricted to determining, by abstraction, the common characters of the given but also, by freely operating the unification of this manifold, shows to be its legislator itself.

Faced with logic as an abstract form indifferent to real otherness (logic not as the logical in the sense of the dialectic soul of all actuality but as the subject of the Science of Logic), and with nature as exteriority, as the unending juxtaposition of beings strictly separate from one another, the spirit is an entity that forms itself by unifying the multiple otherness. It is characterised by its activity of producing its own unity as the sovereign principle of its counterpart. While logic is an abstract interiority, in the sense that it is a unity not invested in differentiated reality, and while nature is an abstract exteriority in the sense that it is a reality strictly lacking unity, the spirit consists in the bringing of exteriority back to interiority. Through the spirit's internally relating itself to this exteriority, it affirms itself as the unitary principle of exterior reality: 'All activities of spirit are nothing but various ways of reducing what is external to the interiority which spirit itself is, and it is only by the reduction, by this idealisation or assimilation of the external that spirit becomes and is spirit' (Hegel 1970d: III, \381, Addition; W:10: 21; Hegel 2007: 12).

It is for this reason that the spirit is never disincarnate, for it is determined by what it renders ideal. It can in no way be thought of as an ether floating imperceptibly over and above the real. On the contrary, it exists in determinate space and time and, more generally, is made concrete through that which it unifies. For example, a 'person' builds itself by taking possession of a given natural good, establishing himself or herself as the unique and unified owner of the thing constituted in itself partes extra partes. Similarly, the prince establishes himself by unifying the opinions of his ministers or the wills of the citizens he governs. This general conception of the spirit constitutes one of Hegel's earliest convictions, since, in the Fragment of a System from 1800, he states: 'We can identify infinite life as spirit, by opposition to abstract multiplicity, for the spirit is the living unity of that which is multiple' (W:1 421).

The spirit cannot be independent of its activity of unification, since it builds itself through its idealisation of the object. Put differently, the spirit's action does not consist in its utilising a presupposed faculty that could conceivably go unused. By acting, the spirit produces itself. Hence it is not merely an act but, more precisely, an acting subject. 
Besides, for Hegel, the spirit is always the spirit in its entirety. It is a totality because it is an active form to be opposed to nature, which is divided since it has a specified content. For instance, a mammal is neither a bird nor a fish; indeed these are limits given to it, so it is obliged to abide by them. By contrast, the spirit consists in the knowing and willing of its own determinations. It is an interiority that invests itself entirely in an exteriority which it thereby makes its own. A spiritual subject is certainly not without limits, but, nevertheless, since it knows and wills its limits, the latter do not make it a part that would be exterior to other parts but, rather, the particular realisation of a universal that exhausts itself entirely in this particularity. For example, although Peter is characterised by a particular body, particular conscious experiences, particular representations, etc., he is absolutely spiritual. For he idealises these facts by making himself their unitary subject. Inasmuch as he represents the knowing and the willing of these properties, Peter is a product of himself. As the negation (sublation) of his negation (given manifold), despite being particular, he is infinite. He is, therefore, not a fraction of the spirit but the spirit as a whole encapsulated in a determinate individuality: 'The animal or the stone knows nothing of its limits. In contrast, the I, as knowing or thinking in general, is limited but knows about the limit, and in this very knowledge the limit is only limit, only something negative outside us, and I am beyond it' (Hegel 1983-1995:1: 317; Hegel 2006: 173).

The Hegelian nature, in my view, is constituted by the conjunction of separate parts: for example, the solar system is the addition of the sun and the several planets, without any immanent link. Even the organic body stems from the association of organs that are not fully unified by the natural soul, which is why the living body is, for Hegel, fundamentally ill and mortal. By contrast, the spirit in general is not constituted by the sum of the individual spirits but is, rather, the universal fully realised in each one of them.

Now, what otherness can be ascribed to the spirit?

In the first place, according to the introduction to the third part of the Encyclopaedia, the spirit 'is this identity only so far as it is at the same time a return out of nature' (Hegel 1970d: III, \381; W:10: 17; Hegel 2007: 9). Similarly, spirit 'itself is this elevation above nature and natural determinacy' (Hegel 1970d: III, \440, Remark; W:10: 230; Hegel 2007: 165). However, the notion of nature used here does not refer exclusively to the external natural world. Naturalness is a structural notion that designates what is immediate, i.e., what is given. For example, Greek religion, according to Hegel, gives crucial importance to the Titanomachy, the battle of the 'ethical' gods led by Zeus against the Titans. The Titans, inasmuch as they are gods, are spiritual, but are also, as indicated by their names (Oceanus, Helius, etc.), powers reigning over nature: 'The essential point is that the Titans are subjugated; the spiritual principle has vanquished nature religion' (Hegel 1983-1995:2: 365; Hegel 1987: 464). In this case, it is clear that the sublation does not only concern the 
exterior nature but also something spiritual, namely, what within the spirit can be considered natural.

More precisely, at the beginning of each cycle, there is an idealisation of outer nature, and then, as the cycle progresses, an idealisation of inner nature. As we know, each systematic moment in Hegel's Encyclopaedia consists in a returning to itself. For example, in the history of religion, we have in the beginning an immediate religion which represents the relation of gods to nature. On the other hand, at the end of the history of religion, in Christianity, God, as self-conscious, is principally in relation to Himself. But my hypothesis is that even then, that is, at the end of the systematic process, the spirit remains related to a certain naturalness, an interior naturalness. For instance, the Christian God, as Christ, is the sublation of finished natural humanity, and, as Holy Spirit, is the sublation of the community of the sinners.

Let us consider another example, the structure of the objective spirit. In the first moment of the objective Spirit, in the abstract right, the spirit is essentially in a relation to external objects, i.e., procurable resources. On the other hand, in the ethical life [Sittlichkeit] (the third moment of the objective spirit), the spirit is in a relation to itself. For example, the Hegelian prince governs the will of the people. But to what extent can we consider that the will of the people to which the prince inclines himself falls into the character of 'nature' or 'naturalness'? According to this argument, the people who are initially presupposed appear as deprived of any unity, given that it is the prince's will alone that confers this unity upon them: 'Taken without its monarch and the articulation of the whole which is necessarily and immediately concomitant of monarchy, the people is a formless mass and no longer a state’ (Hegel 1970c: \$279, Remark; W:7: 447; Hegel 1942: 183). The people, lacking a leader, are thereby without coherent organisation and coordination, remaining a mere juxtaposition of their various groups. Instead of being a whole, they find themselves, in a sense, reduced to the 'state of nature' (status naturae). By this example, we see that, even when the spirit constitutes the sublation no longer of the external environment but of itself, its object is, for all that, a 'natural' object.

However, we may also attempt a more fine-grained study by replacing the twostage analysis used above with a three-stage analysis. Let us consider once again the example of Abstract Right. a) The spirit's first object is the given natural resources themselves. b) It then comes into possession of these resources by entering into a contract. Its second object is thus more 'external' than the first inasmuch as it cannot be immediately appropriated, but rather can only be appropriated given an indefinite series of bilateral agreements. In a way, the world of natural resources, at the first stage, is only 'formally' external, for one grasps the object in question purely and simply through an effort of one's will. It is only at the second stage that the world displays its consistency by requiring the mutual agreement of others in order that the taking possession of the object be legitimate. It is with regard to this second stage that we may use the concept of 'second nature' that Hegel derives from Aristotle. The 
second nature is an objectification of the first nature which was purely formal. c) Finally, the 'principle of rightness' [das Recht an sich] makes itself sovereign over criminal acts and so produces itself as 'right in its actuality' [das wirkliche Recht] (Hegel 1970c: 997, Addition; W:7: 186). There is, then, a return to immediacy, insofar as the spirit no longer consists in the relation to the external natural world of procurable goods. However, the unfair action, as violence, is characterised by Hegel as natural: 'The merely natural will is implicitly a force (Gewalt) against the implicit Idea of freedom’ (Hegel 1970c: \$93, Remark; W:7: 179-80).

Nevertheless, in the second place, I must acknowledge that, in the third stage of each cycle, when the spirit relates directly to itself, the texts make less use of the notion of nature. In reality, everything depends on the way we define this notion: it can either be defined by the idea of immediacy, of the given in general, or, more precisely, by the idea of that which is 'externally' given via the senses. Hegel tends towards this latter definition, which is more restrictive: 'On the whole, the "natural" is understood to mean "the immediate", the sensible generally, the uncultivated' (Hegel 1983-1995:2: 415; Hegel 1987: 518). In the restrictive sense of the natural, spirit is not always sublation of nature or naturalness. However, spirit always sublates real otherness, and when Hegel gives a general definition of spirit, it is also with regard to the naturalness: 'Spirit is essentially this: to be for oneself, to be free, setting oneself over against the natural, withdrawing oneself from immersion in nature, severing oneself from nature and only reconciling oneself with nature for the first time through this severance and on the basis of it' (Hegel 1983-1995: 2, 423; Hegel 1987: 525-26).

\section{The Natural Stage of the Spirit}

Why, then, does Hegel speak of the spirit in the singular, i.e., in general, rather than in the plural, i.e., as a series of distinct spiritual individuals? Clearly, we cannot accept the interpretation that holds that the spirit is a unique entity which would be distinct from the individuals given in experience. For Hegel, there is no spirit beyond experience: the spirit is thus constituted by Peter and by Arthur, by the Greek and Roman states, by the representation of God in historical religions, by the Spinozist and Hegelian philosophies, etc. The problem, however, is with knowing what the unity between these multiple spirits given in experience is. The solution seems to be as follows: the spirit is characterised by a 'conceptual' unity but not by the unity of a 'genus', since it is an activity having always the same goal, but which nonetheless continually differentiates itself from itself by negation. On the one hand, each individual spirit is the subject of an activity of sublation of otherness. On the other hand, we cannot say that the spirit in general has a fixed content, which would always be given and would never truly transform itself. If such was the case, then the spirit 
would not be a product of itself and the negativity of the spirit would only be an apparent negativity.

The fundamental opposition, once again, is that between nature in its strict multiplicity, as a series of objects, and the spirit — which remains always identical with itself - as a subject. It is on the basis of this juxtaposition as the characteristic feature of nature that we are able to grasp why natural beings find themselves in a situation of bellum omnium contra omnes, while spirits are in a position of mutual recognition, of understanding the other as able to live under general principles. The natural being, trapped in its particularity, can only consider another being as a threat, whereas the spirit, which integrates any possible difference, can relate to the other as an alter ego.

However, does this then mean that the spirit is nothing more than a form deprived of any content, drawing its objective being only from its integration of otherness? Put differently, can we say that the spirit is deprived of any inner particularity and is merely an abstract activity of unification? In fact, we cannot, for the spirit relates to real external otherness only in virtue of the fact that it is already realised in itself in a particular way. For example, the consciousness that considers the here and now in the sense-certainty is not absolutely indeterminate, for it is present indeed in a certain space and a certain time. Let us consider another example. According to the presentation in the Lectures on the Philosophy of History, Caesar only transformed the Roman state in virtue of the fact that he lived in a certain country during a certain period, and possessed a particular character, a particular social and family background, etc. His particular inner realisation is that by which he related to a given external reality. Going further, we might hold that it is precisely in virtue of the fact that Caesar idealised his inner content that he could also idealise the external particularity. We are, therefore, not faced with a judgement but with a syllogism: the subject, because it unites with itself, can thereby unite with a determinate external object. The spirit is not an empty form but, rather, always possesses a substantial content. However, this content is not fixed but is unceasingly idealised. Once again, we cannot reduce the spirit to its activity alone; rather, it is the activity of a determinate subject.

Let us continue the investigation into the idea of naturalness. The qualifying term 'natural' does not apply only to the spirit's object but equally to the spirit itself. For example, Hegel refers to the anthropological soul, the first moment of the subjective spirit, as the 'spirit-nature'. The soul, characterised by adherence to a particular ethnicity, character, sex, etc., constitutes a given which serves as the starting point for the manifestation, in the subjective spirit, of consciousness and of the theoretical and practical spirit. This development of the subjective spirit, then, consists in denying the purely anthropological dimension of the spirit for the sake of consciousness (the second moment) and subjective thought (the third moment). 
Let us now consider the following statement: 'In the beginning we have only the wholly [...] undeveloped determination of spirit, not yet its particularity. [...] [For example] the child is still caught up in naturalness, has only natural urges, is a spiritual human being not yet in actuality but only in potentiality’ (Hegel 1970d: III, \385, Addition; W:10: 33; Hegel 2007: 20). We see here that initially the spirit has only one given reality, as shown by the example of the child. The child does not give birth to himself or herself by his or her activities, yet he or she is always already present as a subject able to act spiritually. Moreover, a man is what a child becomes when he sublates his own immaturity. It thus appears that the spirit's action is conditioned by a presupposition which is none other than the starting spirit itself, as the object of the fulfilled spirit. The activity of the spirit is that of an agent which is, initially, only 'immediately' spiritual, and which tends to realise itself as 'actually' spiritual.

Naturalness associates the idea of the originally given essence with the idea of the perceptible surrounding world. The naturalness of a process defines what it is at its origin and in itself. But it also names its own existence inasmuch as it is swallowed up by the sensuous externality, given that it has not yet been internalised. In the preceding part of this paper, I supported the view that the spirit always relates, in the form of an act, to a presupposed substance that can be qualified as natural. It now appears that it is essentially to itself, as a given substance, that the spirit relates. Its task is actively to produce its identity as a spiritual subject by denying its given substantial starting point:

The concept of spirit necessarily advances to this development of its reality, for the form of immediacy, of indeterminacy, which its reality initially has, is a form in contradiction with the concept. [...] Spirit is impelled by this contradiction to sublate the immediate, the Other, the form that is, in which it presupposes itself. By this sublation it first comes to itself, first emerges as spirit. (Hegel 1970d: III, §385, Addition; W:10: 33; Hegel 2007: 21)

We can now quickly compare logic and spirit. As we know, logic designates the life of the pure thought: not the thought of a thinking spirit but intelligibility considered in itself. More precisely, logic is not only thought as a given content [der Gedanke] but as an active form [das Denken] (Hegel 1970d: I, \$24, Addition; W:8: 84). The difference between logic and spirit is thus as follows: the former is never truly confronted with the threat of the non-logical, whereas the latter must constantly deal with an otherness which is non-spiritual. Of course, in logic there is a diversity of contents. But these contents always remain of a logical order. They share immediately and constantly a fundamental identity, so that the difference in logic is only 'formal'. In contrast, the spirit must rise above a difference which is 'real'. The spirit's task is to render its identity actual through a process of Bildung. Recognition, in the sense of establishing one's unity with others - whatever the form and implications of this 
unity may be - does not lie simply in the fact of registering an identity that is already there. It is, rather, the engendering of this unity at the expense of an original opposition.

\section{From the Origin to the Fulfilment}

By its acts, the spirit transfigures its original essence and produces itself as its leading subject. Hegel here returns to a traditional idea, which finds its origin in Plato's Protagoras and makes of man a naturally helpless being, but a being that is essentially perfectible: 'This peculiarity in the world of spirit has indicated in the case of man an altogether different destiny from that of merely natural objects — in which we find always one and the same stable character, to which all change reverts; - namely, a real capacity for change, and that for the better — an impulse of perfectibility' (W:12: 74; Hegel 2004: 54).

The difficulty, however, is in grasping how exactly the spirit can tend towards reason and thus be at once rational and irrational. The notion of the naturalness of the spirit responds to this difficulty. The notion refers to this presupposed origin, which is unsatisfactory because it is non-total but which is nonetheless incontestably spiritual. The spirit is in the beginning just a given spirit and must freely become its own work. It is entrusted to itself and its actuality consists precisely in the carrying out of the sublation of itself.

But is this theory not circular in some way? It is common to blame Hegel for presupposing what he should demonstrate, and notably for presupposing the spirit's capacity to carry out the sublation of all finite reality. The Encyclopaedia would be, in that case, a vast petitio principii. The very success of the spirit gives rise to the following suspicion: does Hegel not attribute to the spirit an ability that it does not have? Or more simply: doesn't the philosopher unduly escape giving an account of the spirit's ability? This objection must be taken seriously, yet we can also show its limitations.

In reality, there is nothing surprising in this ability, inasmuch as the spirit consists in establishing the ideal sense of the real. For example, if the spirit in an intuition synthetically grasps space as a whole, even while physical space is constituted partes extra partes, it simply understands it at the level of thought. In what way could the dividing up of physical space offer the slightest resistance to its being unified in the intellect? The spirit's task is not to modify 'in reality' the natural properties of space but only 'ideally'. In the same way, if an individual, when looking out over an area of land, declares 'this is mine', it would be absurd to imagine that the land itself could constitute an obstacle to the act of appropriation. The taking possesion of the land is as such actual, since it is nothing other than a decision of the will. 
Hegel often describes the spiritual sublation of otherness as 'prodigious' [ungehener]. Nonetheless, we must note that this prodigy is in no way inconceivable, for it is founded on the capacity for conviction of rationality. For example, as Hegel states in his Lectures on the Philosophy of History, the great men easily assemble the peoples around their banners (Hegel 1996: 68). Similarly, the Lecture on Nature in $1823 / 24$ contains the remark that meaningful political discourse unfailingly wins the assent of its listeners: 'All men are in themselves rational, the man of power calls on their instinct to reason, and that which he makes clear to them possesses an equivalent among them. In this way, reason appears and grows irresistibly among the people' (Hegel 2000: 253). This, clearly, is a debatable element of Hegelian doctrine. But, in the history of philosophy, this confidence in the power of reason, this conviction that it unfailingly prevails over instinct as soon as it is constituted, is extremeley classical.

The difficulty, however, lies in admitting the very existence of the spirit. We saw that it does not proceed from nature but, rather, sublates given naturalness. At this point, the question arises: where does the spirit come from? Must we not suspect Hegel, at each moment in the development of his system, of too generously granting himself what in reality he ought to explain, namely, the origin of the spirit? Is not the spirit like the baron Munchausen, pulling on his own plaits to drag himself out of the bog in which he is stuck? At this point, four remarks can be made.

Firstly, there is actually a presupposition in each cycle of the spirit, namely, its 'natural' moments. As we have noted, Hegel's philosophy admits that the starting point is given. However, there is no incoherence to be found here. On the contrary, it would be extravagant to demand that the starting point be mediated. The starting point is realistic, only the result is idealistic.

Secondly, this presupposition is not the doing of the philosopher, who would here seek asylum for his ignorance, but rather the doing of the thing itself, insofar as the latter appears as a brute fact, without giving any account of or any justification for itself. For example, the Oriental state, at the beginning of political history, is deprived of justification; it constitutes, we might say, nothing more than violence exercised by a despot who rules over his subjects. However, the coming about of a given nonrational state is not the invention of the philosopher; it is due to the state itself which spontaneously brings about its own existence.

Thirdly, the beginning spirit, as we saw above, is not actually spiritual. While the actual spirit consists in the act carrying out the rational idealisation of objective reality, the originating spirit is characterised by irrationality and powerlessness. For example, the individual in his or her anthropological 'naturalness' is reduced to his or her sense experience and to the idealisation, by the soul, of nothing other than the body. The individual is then deprived of true knowledge and will, since sensation does not provide one with knowledge, and one's control over one's own body does not imply any freedom. We could make an analogous remark about the child with regard 
to the ages of life, about sense certainty with regard to the development of consciousness, or indeed about symbolic art with regard to the history of art. The beginning of all this is not the presupposition of the true spirit but, rather, the presupposition of the spirit as something which is not what it ought to be. The thing in its initial state is the exact opposite of its actual reality. To be more precise, the complete realisation of any given cycle consists in the 'infinite' negation of its initial state. Thus we cannot accuse the presupposed starting point of always according itself the actuality of the spirit, for the origin is indeed what must be left behind in order for the spirit to realise itself. By initially presupposing itself, the spirit produces itself as actual through the negation of its original being. There is a given starting point that much can be granted — but the subject itself only becomes actual through its own work. True spirit is neither always already there, nor causa sui, but forms itself by the sublation of its initial reality and of its dissociation from itself.

Fourthly, the fact that the spirit is not derivable from some other thing is nothing but the correlate of its freedom. We cannot deduce the spirit from anything other than itself, precisely because it confides in itself. The spirit is only what it makes itself in virtue of a knowing and a willing that are its own: 'It brings itself forth from the presuppositions that it makes for itself (Hegel 1970d: III §381, Addition; W:10: 24; Hegel 2007: 14-15). Whereas the natural being is dependent on its external surroundings, and is thus contingent, the spiritual spirit only depends on itself; this is the very reason for its freedom.

To conclude, I would like to emphasise that the spirit, in contrast with nature, gives a true place both for the beginning and for the conclusion. The following remark from Reason in History is significant: 'The powerlessness of natural life appears [for example] in the fact that the seed is at once the beginning and the result of the individual. As a starting point and as a result it is different and nevertheless identical, being the product and the beginning of another' (Hegel 1955: 58). In nature, there is neither true beginning nor true end, for everything results from something else and is also a starting point for another. Nothing in nature is truly initial or terminal. On the other hand, the spiritual subject is a totality in itself. It is for this reason that it always exists through itself, just as much at its starting point as at its point of fulfilment. In order to exist, it needs nothing other than itself, since otherness is not one of its causes or its positive conditions but rather the negative material of its self-affirmation. When completed, the spirit does not serve as a means for some other thing, but contents itself with itself — following the example of Aristotle's God, noèsis noèseôs. Each cycle of the spirit progresses from a radical beginning to an ultimate fulfilment, for it constitutes its own origin and completes itself through itself.

\section{Gilles Marmasse}

Université Paris-Sorbonne 


\section{Bibliography}

Hegel, G. W. F. (1942), Philosophy of Right, trans. T. M. Knox. Oxford: Clarendon Press. Hegel, G. W. F. (1955), Einleitung in Die Vernunft in der Geschichte, ed. J. Hoffmeister. Hamburg: Meiner.

Hegel, G. W. F. (1970a), Werke in zwanzig Bänden, ed. E. Moldenhauer and K. M. Michel. Frankfurt: Suhrkamp.

Hegel, G. W. F. (1970b), Frühe Schriften, vol. 1 of Werke.

Hegel, G. W. F. (1970c), Rechtsphilosophie, vol. 7 of Werke.

Hegel, G. W. F. (1970d), Enzyklopädie der philosophischen Wissenschaften, vols 8-10 of Werke.

Hegel, G. W. F. (1970e), Vorlesungen über die Philosophie der Geschichte, vol. 12 of Werke. Hegel, G. W. F. (1983-1995), Vorlesungen über die Philosophie der Religion, ed. W. Jaeschke. Hamburg: Meiner, 3 Bde.

Hegel, G. W. F. (1987), Determinate Religion, ed. P. C. Hodgson, trans. R. F. Brown, P. C. Hodgson and J. M. Stewart. Oxford: Clarendon Press.

Hegel, G. W. F. (1996), Vorlesungen über die Philosophie der Weltgeschichte, Berlin 1822/1823, ed. K. H. Ilting, K. Brehmer and H. N. Seelmann. Hamburg: Meiner.

Hegel, G. W. F. (2000), Vorlesung über Naturphilosophie, Berlin 1823/24, ed. G. Marmasse. Frankfurt: Peter-Lang.

Hegel, G. W. F. (2004), Lectures on the Philosophy of History, trans. J. Sibree. Mineola, NY: Dover Publications.

Hegel, G. W. F. (2006), Lectures on the Philosophy of Religion, The lecture of 1827, ed. P. C. Hodgson, trans. R. F. Brown, P. C. Hodgson and J. M. Stewart. Oxford: Clarendon Press. Hegel, G. W. F. (2007), Philosophy of Mind, trans. W. Wallace, V. Miller and M. Inwood. Oxford: Clarendon Press. 